\begin{tabular}{|c|c|}
\hline Title & Nony Iphenol diethoxy late inhibits apoptosis induced in PC12 cells \\
\hline Author(s) & Liu, Chuang; Sun, Y ongkun; Song, Y utong; Saito, Takeshi; Kurasaki, Masaaki \\
\hline Citation & $\begin{array}{l}\text { Environmental Toxicology, 31(11), } 1389-1398 \\
\text { https://doi.org/10.1002tox.22144 }\end{array}$ \\
\hline Issue Date & 2016 \\
\hline Doc URL & http:/hdl.handle.net/2115/65152 \\
\hline Rights & $\begin{array}{l}\text { This is the peer reviewed version of the following article: http://onlinelibrary.wiley.com/doi/10.1002/tox.22144/epdf, } \\
\text { which has been published in final form at } 10.1002 \text { tox.22144. This article may be used for non-commercial purposes in } \\
\text { accordance with Wiley Terms and Conditions for Self-A rchiving. }\end{array}$ \\
\hline Type & article (author version) \\
\hline File Information & Liu Chuang's Manuscript20150313.pdf \\
\hline
\end{tabular}

Instructions for use 


\section{Nonylphenol diethoxylate inhibits apoptosis induced in PC12 cells}

Chuang Liu ${ }^{1}$, Yongkun Sun ${ }^{2,3}$, Yutong Song ${ }^{1}$, Takeshi Saito ${ }^{4}$, Masaaki Kurasaki ${ }^{1,3}$

${ }^{1}$ : Graduate School of Environmental Science, Hokkaido University, Sapporo 060-0810, Hokkaido, Japan,

2. Department of Basic Medicine, Xinxiang Medical University, Xinxiang 453-003, Henan, China,

${ }^{3}:$ Faculty of Environmental Earth Science, Hokkaido University, Sapporo 060-0810, Japan

${ }^{4}$ : Faculty of Health Sciences, Hokkaido University, Kita 12 Nishi 5, Kita-ku, Sapporo 060-0812, Japan

Short title: $\mathrm{NP}_{2} \mathrm{EO}$ inhibits apoptosis

Corresponding address

Dr. Masaaki Kurasaki

Faculty of Environmental Earth Science, Hokkaido University

Kita-10, Nishi-5, Kita-ku, Sapporo 060-0812, JAPAN

e-mail; kura@ees.hokudai.ac.jp, Fax:+81-11-706-4864 
ABSTRACT: Nonylphenol and short-chain nonylphenol ethoxylates such as $\mathrm{NP}_{2} \mathrm{EO}$ are present in aquatic environment as wastewater contaminants, and their toxic effects on aquatic species have been reported. Apoptosis has been shown to be induced by serum deprivation or copper treatment. To understand the toxicity of nonylphenol diethoxylate, we investigated the effects of $\mathrm{NP}_{2} \mathrm{EO}$ on apoptosis induced by serum deprivation and copper by using PC12 cell system. Nonylphenol diethoxylate itself showed no toxicity and recovered cell viability from apoptosis. In addition, nonylphenol diethoxylate decreased DNA fragmentation caused by apoptosis in PC12 cells. This phenomenon was confirmed after treating apoptotic PC12 cells with nonylphenol diethoxylate, whereas the cytochrome c release into the cytosol decreased compared to that in apoptotic cells not treated with nonylphenol diethoxylates. Furthermore, Bax contents in apoptotic cells were reduced after exposure to nonylphenol diethoxylate. Thus, nonylphenol diethoxylate has the opposite effect on apoptosis in PC12 cells compared to nonylphenol, which enhances apoptosis induced by serum deprivation. The difference in structure of the two compounds is hypothesized to be responsible for this phenomenon. These results indicated that nonylphenol diethoxylate has capability to affect cell differentiation and development and has potentially harmful effect on organisms because of its unexpected impact on apoptosis.

Keywords: Nonylphenol diethoxylate; nonylphenol; apoptosis; cytochrome c; PC12 cells 


\section{INTRODUCTION}

Alkylphenol ethoxylates (APEOs) are nonionic surfactants found in industrial, institutional, and household products. Nonylphenol ethoxylates (NPEOs) are the most commercially abundant APEOs, representing about $80 \%$ of the market (APERC, 2006). NPEOs are often used in non-agricultural pesticides, cosmetic and cleaning products, and correction fluids and inks (Stasinakis et al., 2008). Because of the widespread application of these products, NPEOs enter the environment via industrial effluents and wastewater. NPEOs released into the environment are biodegraded to shorter-chain metabolic intermediates including nonylphenol (NP), nonylphenol monoethoxylate $\left(N P_{1} E O\right)$, and nonylphenol diethoxylate $\left(N_{2} E O\right)$ by the loss of ethoxylates (EO) (Ahel et al., 1994), which are more toxic, lipophilic, and stable compared to long chain NPEOs (Ying, 2006; Sharma et al., 2009). In recent years, the toxicity of NPEOs and NP has been studied particularly in the aquatic environment (Vazquez et al., 2005; Soares et al., 2008). The toxicity of NPEOs to aquatic organisms increases as the length of ethoxylates chain decreases (Teneyck and Markee, 2007). NP and short chain NPEOs are frequently identified as major contaminants in waste and even drinking water (Ying, 2006; Soares et al., 2008; Sharma et al., 2009). Recently, these sub-products have been detected in vegetables (Cai et al., 2012).

NP and NPEOs are toxic to both aquatic and terrestrial organisms probably as a result of their interaction with proteins (Scott and Krogh, 2004). NPEOs are produced by a base catalyzed reaction of ethylene oxide with NP (Naylor, 1995). NP and NPEOs have different structures; hence, they disrupt differently the biochemical processes in organisms. It has been reported that enzymes such as P-glycoprotein interact with various NPEO compounds, but not with NP (Loo et al., 1998). NP exhibits stable hydrophobicity and has limited biodegradation potential (Tollefsen et al., 2008). It accumulates in organisms, and causes acute toxicity to algae, clams, shrimp, crustaceans, and fish (Tollefsen et al., 1998). NP and short chain NPEOs have also been reported to interact with intracellular and extracellular estrogen binding proteins (Knudsen and Pottinger, 1999), and to interfere with reproductive functions and normal development of fish (Jobling et al., 1996; Seki et al., 2003).

It was found that more than $80 \%$ of the male Medaka exposed to concentrations of $50 \mu \mathrm{g} / \mathrm{L}$ to $100 \mu \mathrm{g} / \mathrm{L}$ NP exhibited gonadal intersex (i.e., intermediate characteristics between males and 
females). Treatment with $300 \mu \mathrm{g} / \mathrm{L} \mathrm{NP}_{1}$ EO produced a similar outcome, indicating that when NP was mixed in $\mathrm{NP}_{1} \mathrm{EO}$, the toxicity of $\mathrm{NP}_{1} \mathrm{EO}$ was enhanced. Because of the differences in the structure of the two compounds, NP had a much stronger effect on fish and mammals compared to the short chain NPEOs (Balch et al., 2006).

Some studies have demonstrated that NPEOs with relatively small number of EO units $(s=0-30)$ showed greater cytotoxicity (inhibition of cell proliferation) in human skin fibroblast cells compared to long chain NPEOs (Goto et al., 2004). The genotoxic effects of NPEOs on mammalian cells have also been studied. NPEOs were found to cause direct DNA damage (DSBs, double strand breaks), but did not contribute to reactive oxygen species (ROS) (Toyooka et al., 2012). NPEOs also act as tumor initiators and promoters. In contrast, NP decreases the viability of Raji cells via ROS (Qi et al., 2013). These differences of the effect of NPEOs and NP may be dependent on their structures, although the reason for the observed discrepancy between NP and short chain NPEOs remains unclear.

Most of the research on NPEOs degradation from NP has focused on the growth of reproductive organs in rats (Laws et al., 2000; Lee et al., 1996; Odum et al., 1999). Beside reproductive organs, NP also affects nonreproductive organs, such as kidney and liver (Chapin et al., 1999; Nagao et al., 2001). It has been found that hydroxyl radical formation in the striatum was induced in rats treated with NP, which might contribute to certain stages in the advancement of brain damage (Obata and Kubota, 2000). Furthermore, behavioral alterations were observed in the open-field activity of rat offspring exposed to NP (Ferguson et al., 2000). These findings indicate that NP may affect the central nervous system. Thus, NP deleteriously affects several organs, in addition to adipose tissue and adipocytes (Ferguson et al., 2000; Obata and Kubota, 2000; Masuno et al., 2003). However, the effects of short chain NPEOs on cells or organisms have received comparatively little attention because of its smaller toxicity compared to NP.

Few studies have demonstrated the influence of NPEOs on three cell lines; namely, ASF4-1 cells, Jurkat cells, and NIH3T3 cells, which represent normal human skin fibroblasts, human leukemia cells, and mouse fibroblasts, respectively. Certain $\mathrm{NP}_{70} \mathrm{EO}$ showed no cytotoxicity in any of the cell lines, whereas other $\mathrm{NP}_{10} \mathrm{EO}$ exhibited significant toxicity. $\mathrm{NP}_{10} \mathrm{EO}$ toxicity was caused by detachment of cells due to the structural change of the cell membrane. In addition, it was also shown that cytotoxicity was dependent on the number of EO units in all three cell lines. With 
decreasing the number of EO units, cell proliferation was increasingly inhibited (Goto et al., 2004). Moreover, $\mathrm{LD}_{50}$ of NPEOs ( $\mathrm{s}=1.5,9,15,40$, and 50) in Mysidopsis bahia was 0.11, 1.41, 2.57, over 100 and over $4110 \mathrm{mg} / \mathrm{L}$, respectively (Goto et al., 2004). These findings indicate that the toxicity of NPEOs increases with decreasing the number of EO units. Further detailed cytotoxicity studies of short chain NPEOs are needed.

PC12 is a rat pheochromocytoma clonal cell line that responds to nerve growth factor by extending neurites, thus acquiring the appearance of neurons (Greene and Tischler, 1976). PC12 cells have become a very suitable model to study neuronal function and differentiation (Vaudry et al., 2002; Ravni et al., 2006). On the other hand, it is well known that apoptosis is induced by serum deprivation in PC12 cells (Maroto and Perez-Polo, 1997). Recently, we have reported that some endocrine disrupters inhibited apoptosis induced by serum deprivation (Yamanoshita et al., 2000; 2001). In addition, we have examined whether NP affects apoptosis in PC12 cells. Our results of DNA fragmentation and relative expression of apoptotic factors indicated that NP enhances apoptosis induced by serum deprivation in PC12 cells (Aoki et al., 2004). The effects of short chain NPEOs on apoptosis have not been clarified, although it is expected that the toxicity of NPEOs will decrease with increasing the number of EO units. Apoptosis is a physiological cell-death mechanism commonly associated with programmed events, including morphological and biochemical changes, which are necessary for the differentiation and development of organs and organisms (Maroto and Perez-Polo, 1997). Investigation of effects on apoptosis is expected to contribute new insight into the mechanisms of the effect of NPEOs on the differentiation and development of an organism. In addition, PC12 cells are a good model for study of apoptotic changes because apoptotic condition can be regulated by bovine fetal albumin (Maroto and Perez-Polo, 1997) and copper (Kawakami et al., 2008). The objective of our study is to investigate the role of NPEOs regulation of the changes of apoptotic status caused by serum deprivation or copper, and to clarify the mechanisms of the effects of short chain NPEOs on apoptotic conditions. The significance of obtained results was discussed in detail.

\section{MATERIALS AND METHODS}

\section{Materials}


PC12 cells were purchased from the American Type Culture Collection (USA and Canada). Dulbecco's modified Eagle medium (DMEM), ribonuclease $A$ and o-phenylenediamine dihydro chloride (OPD) were obtained from Sigma-Aldrich (St. Louis, MO, USA). NP ${ }_{2} E O$ was purchased from Tokyo Chemical Industry Corporation (Tokyo, Japan). Fetal bovine serum (FBS) was obtained from HyClone (Rockville, MD USA). Monoclonal antibody against cytochrome c, and polyclonal antibody against $\mathrm{Bcl}-2$ were from Santa Cruz Biotechnology (Santa Cruz, CA, USA). Nonradioactive cytotoxicity assay kit and purified horseradish peroxidase conjugate of goat anti-mouse $\lg G(\mathrm{H}+\mathrm{L})$ were obtained from Promega (Madison, WI, USA). Polyclonal antibody against Bax was provided by Calbiochem (San Diego, CA, USA). Anti-rabbit immunoglobulin peroxidase conjugate was obtained from Amersham Bioscience UK Limited (UK). Amersham ${ }^{\mathrm{TM}} \mathrm{ECL}^{\mathrm{TM}}$ western blotting detection reagents were obtained from GE Healthcare UK Limited (UK). The High Pure PCR template Preparation Kit for genomic DNA and Proteinase K was obtained from Roche Diagnostics (Basel, Switzerland). Trypan blue stain solution (0.5\%) was obtained from Bio-Rad (Hercules, CA, USA). The Cytochrome c Releasing Apoptosis Assay kit was from Medical and Biological Laboratories Co., Ltd (Japan). All other chemicals were analytical grade.

\section{Cell Culture}

PC12 cells were cultured in DMEM supplemented with $10 \% \mathrm{FBS}$ in a humidified incubator at $37^{\circ} \mathrm{C}$ and $5 \% \mathrm{CO}_{2}$. The cells were pre-incubated overnight in Nunclon TM Delta treated $25-\mathrm{cm}^{2}$ flasks (ThermoFisher Scientific; Waltham, MA, USA), and the medium was then replaced with serum/serum-free DMEM with and without $\mathrm{NP}_{2} \mathrm{EO}$, and serum $\mathrm{DMEM}$ containing $\mathrm{CuSO}_{4}$ with and without $\mathrm{NP}_{2} \mathrm{EO}$. Before the transfer to the serum-free medium that was replaced with medium without serum, the cells in the flask were washed twice with serum-free DMEM.

\section{Cell Viability}

Cell viability was measured by trypan blue exclusion assay. PC12 cells were incubated in the serum and serum-free medium with $0-1 \mu \mathrm{g} / \mathrm{mL}$ of $\mathrm{NP}_{2} \mathrm{EO}$ or serum medium containing $0-500 \mu \mathrm{M}$ copper with and without $\mathrm{NP}_{2} \mathrm{EO}$ for $72 \mathrm{~h}$. After incubation, the cells were stained in $0.25 \%$ trypan blue solution in phosphate-buffered saline (PBS). Total cells and trypan blue-stained cells were counted 
using a hemocytometer (TC10 ${ }^{\mathrm{TM}}$ Automated Cell Counter, Bio-Rad). Cell viability was expressed as a percentage against the total cell number in each experiment. Each experiment was repeated 3-6 times.

\section{DNA Extraction from PC12 Cells}

The PC12 cells were incubated in serum/serum-free DMEM containing $0-1 \mu \mathrm{g} / \mathrm{mL} \mathrm{NP}{ }_{2}$ EO or serum DMEM containing 0-500 $\mu \mathrm{M} \mathrm{CuSO}_{4}$ with and without $\mathrm{NP}_{2} \mathrm{EO}$ for $72 \mathrm{~h}$. After the treatment, the cells were harvested with a scraper and transferred into $15-\mathrm{mL}$ tubes. The cells were washed with $1 \times$ PBS. Genomic DNA was isolated with High Pure PCR Template Preparation Kit following the manufacturer's instructions. Finally, the DNA was recovered using ethanol precipitation method.

The DNA ladder pattern was quantified using agarose gel electrophoresis. From $3 \mu \mathrm{g}$ to $5 \mu \mathrm{g}$ of DNA was subjected to electrophoresis on $1.5 \%$ agarose gel. After electrophoresis, the gel was soaked in ethidium bromide solution for $15 \mathrm{~min}$ in the dark, and DNA was visualized and photographed under UV illumination with ChemiDoc XRS (Bio-Rad) to determine the extent of cell death. Density of the DNA ladder was estimated by Image J software.

\section{Western Blotting Analysis of Cytochrome c Release in Cytosol}

Cytochrome c release in the cytosol was assessed using Cytochrome c Release Apoptosis Assay Kit (Calbiochem, Darmstadt, Germany). The cells prepared following kit instructions were disrupted by sonication for $30 \mathrm{~s}$ in a Sonifier 250 (Branson Ultrasonic). Lysed cells were separated from the intact cells by centrifugation at $650 \times \mathrm{g}$ for $5 \mathrm{~min}$. Each supernatant was transferred into a separate $1.5-\mathrm{mL}$ tube and centrifuged at $10,000 \times \mathrm{g}$ at $4^{\circ} \mathrm{C}$ for $30 \mathrm{~min}$. The treated lysate including released cytochrome c (20-30 $\mu \mathrm{g}$ proteins) was separated by polyacrylamide gel electrophoresis (12.5\% polyacrylamide for the separation gel and 3\% for the stacking gel), and the electrophoresed proteins were transferred to nitrocellulose membranes with a wetting blotting system, type-AE6678 (ATTO, Tokyo, Japan). The membranes were incubated overnight at $4^{\circ} \mathrm{C}$ in $0.15 \%$ Tween-20, $40 \mathrm{mM}$ Tris- $\mathrm{HCl}$ buffer, pH 7.4, containing $150 \mathrm{mM} \mathrm{NaCl}$ and $2.5 \mathrm{~g}$ dry non-fat milk. The membranes were incubated for $45 \mathrm{~min}$ at $37^{\circ} \mathrm{C}$ with anti-cytochrome c antibody (dilution 1: 200) in 0.15\% Tween-20, $40 \mathrm{mM}$ Tris- $\mathrm{HCl}$ buffer ( $\mathrm{pH}$ 7.4), and $150 \mathrm{mM} \mathrm{NaCl}$. The membranes were washed with the same buffer for 
3 min 3 times, and then incubated at $37^{\circ} \mathrm{C}$ for 30 min using anti-mouse IgG-conjugated peroxidase as a secondary antibody (dilution; 1: 2500) in the same buffer. The membranes were washed for 3 min 5 times. Finally, the protein bands that responded to antibodies were detected with an enhanced chemiluminescence imaging system (ChemiDoc XRS, Bio-Rad). The cytochrome c content was measured using Image J software.

\section{Enzyme Linked Immune-Sorbent Assay (ELISA) of BAX and BCL-2 in PC12 Cells}

The ELISA procedure was carried out according to Yamanoshita et al. (2000). The cells under different experimental settings were washed with $1 \times$ PBS and harvested by centrifugation at $650 \times g$ for $5 \mathrm{~min}$. The cells were resuspended in the lysis buffer consisting of $2 \mathrm{mM} \mathrm{HEPES,} 100 \mathrm{mM} \mathrm{NaCl}$, $10 \mathrm{mM}$ EGTA, $1 \mathrm{mM}$ PMSF, $1 \mathrm{mM} \mathrm{Na}_{3} \mathrm{VO}_{4}, 0.1 \mathrm{mM} \mathrm{Na}_{2} \mathrm{MoO}_{4}, 5 \mathrm{mM}$ b-glycerophosphoric acid disodium salt, $50 \mathrm{mM} \mathrm{NaF}, 1 \mathrm{mM} \mathrm{MgCl} 2,2 \mathrm{mM}$ DTT, and $1 \%$ TritonX-100, and disrupted by sonication (Branson Sonifier 250) for 30 s. The cell debris and intact cells were removed by centrifugation. The contents of $\mathrm{BAX}$ and $\mathrm{BCL}-2$ in the cell extracts of the sample solution were measured by ELISA. In brief, $100 \mu \mathrm{L}$ of each sample was placed in titerplate wells. The plate was incubated for $1 \mathrm{~h}$ at $37^{\circ} \mathrm{C}$. After the incubation, the titerplate was washed twice with $40 \mathrm{mM}$ Tris- $\mathrm{HCl}$ buffer, $\mathrm{pH} 7.4$, containing $150 \mathrm{mM} \mathrm{NaCl}$ and $0.05 \%$ Tween-20 and blocked by adding $200 \mu \mathrm{L}$ of the same buffer containing $2 \%$ blocking reagent. The plates were then incubated for $1 \mathrm{~h}$ at $37^{\circ} \mathrm{C}$. The first antibody for BAX or BCL-2 (1:750 or 1:100 diluted with the same buffer) was immobilized with antigens in the samples for $1 \mathrm{~h}$ at $37^{\circ} \mathrm{C}$. Then, the plate was washed with the same buffer 3 times. The second antibody, an anti-rabbit immunoglobulin peroxidase (1:500 diluted with the same buffer), was added and the plate was incubated for $1 \mathrm{~h}$ at $37^{\circ} \mathrm{C}$. Then the plate was washed with the same buffer 5 times. After washing, 0.1\% OPD in $50 \mathrm{mM}$ phosphate-citrate buffer, pH 5.0, containing $0.03 \%$ sodium perborate was added into the wells. After $10 \mathrm{~min}, \mathrm{HCl}$ was added to stop the enzyme reaction. Absorbance at $495 \mathrm{~nm}$ was measured with Microplate Reader model 450 (Bio-Rad).

\section{Statistical Analysis}

Each value is expressed as the mean \pm S.E. Statistical analyses were performed by the student's 
t-test.

\section{RESULTS}

\section{Cell Viability}

To evaluate the cytotoxicity of $\mathrm{NP}_{2} \mathrm{EO}$, cell viability was measured by trypan blue staining after the PC12 cells were exposed to $0,0.1$ and $1 \mu \mathrm{g} / \mathrm{mL} \mathrm{NP}{ }_{2}$ EO for $72 \mathrm{~h}$. As shown in Fig. $1 \mathrm{~A}$, no significant difference in viability was observed in cells exposed to 0.1 or $1 \mu \mathrm{g} / \mathrm{mL} \mathrm{NP}{ }_{2}$ EO compared to the viability of cells cultured in serum medium without $\mathrm{NP}_{2} \mathrm{EO}$. A significant decrease in viability was observed in cells cultured in the serum-free medium free of $\mathrm{NP}_{2} \mathrm{EO}$. Furthermore, after the addition of $\mathrm{NP}_{2} \mathrm{EO}$ to the serum-free medium, a significant increase of cell viability was observed between 0.1 and $1 \mu \mathrm{g} / \mathrm{mL} \mathrm{NP}{ }_{2}$ EO (Fig. 1B).

Cell viability in the serum medium containing $\mathrm{CuSO}_{4}(500 \mu \mathrm{M})$ decreased significantly (Fig. 2). When copper and $\mathrm{NP}_{2} \mathrm{EO}$ were co-present in the medium for PC12 cells, cell viability significantly increased compared to the cells exposed to copper only. Therefore, $\mathrm{NP}_{2} \mathrm{EO}$ recovers viability of copper treated cells.

\section{DNA Fragmentation by Agarose Gel Electrophoresis}

To investigate the effect of $\mathrm{NP}_{2} \mathrm{EO}$ on apoptosis, DNA fragmentation of PC12 cells cultured in serum/serum-free medium with and without $\mathrm{NP}_{2}$ EO was studied (Fig. 3).

DNA fragmentation was observed when apoptosis was induced by serum-deprivation in the cells (Fig. 3B), and it was absent in PC12 cells cultured in the serum containing medium with 0-1 $\mu \mathrm{g} / \mathrm{mL} \mathrm{NP}{ }_{2} \mathrm{EO}$ (Fig. 3A). These results indicate that $\mathrm{NP}_{2} \mathrm{EO}$ does not induce apoptosis in PC12 cells. On the other hand, the DNA ladder pattern gradually decreased in cells cultured in the serum-free medium in a dose-dependent manner of $\mathrm{NP}_{2} \mathrm{EO}$ (Fig. 3B). In addition, the densities of the DNA

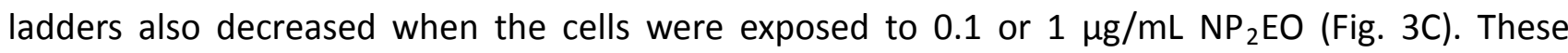
results indicate that $\mathrm{NP}_{2} \mathrm{EO}$ reduce the apoptosis induced by serum deprivation in PC12 cells.

As expected, the same DNA fragmentation pattern was observed in the serum medium containing $\mathrm{CuSO}_{4}(500 \mu \mathrm{M})$ treated with 0.1 or $1 \mu \mathrm{g} / \mathrm{mL} \mathrm{NP}{ }_{2} \mathrm{EO}$ (Fig. $\left.4 \mathrm{~A}\right)$. NP ${ }_{2}$ EO reduced the DNA fragmentation in the cells grown in serum medium containing $\mathrm{CuSO}_{4}$, with the densities of DNA 
ladders also decreasing when the cells were exposed to 0.1 or $1 \mu \mathrm{g} / \mathrm{mL} \mathrm{NP}_{2} \mathrm{EO}$ (Fig. 4B).

\section{Detection of Cytochrome c Release by Western Blotting}

As shown in Fig. 5B, no significant changes in cytochrome c release were observed among the cells cultured in serum medium with and without $\mathrm{N}_{2} \mathrm{PEO}$. These results further confirmed that $\mathrm{NP}_{2} \mathrm{EO}$ does not induce apoptosis. Yet, after treating PC12 cells with $\mathrm{NP}_{2} \mathrm{EO}$ in the serum-free medium, cytochrome c content declined in comparison to the PC12 cells without $\mathrm{NP}_{2} \mathrm{EO}$ (Fig. 5A). Hence, relatively low concentrations of $\mathrm{NP}_{2} \mathrm{EO}$ might inhibit the apoptosis induced by serum deprivation in PC12 cells.

Furthermore, the cytochrome c release decreased significantly in PC12 cells cultured in serum medium containing copper with 0.1 or $1 \mu \mathrm{g} / \mathrm{mL} \mathrm{NP}{ }_{2} \mathrm{EO}$ (Fig. 6). Thus, $\mathrm{NP}_{2} \mathrm{EO}$ reduced the cytochrome c release under the apoptotic situation caused by copper.

\section{Contents of BAX, BCL-2 in PC12 Cells by ELISA}

To examine whether bcl-2 family is related to reduction of apoptotic situation caused by $\mathrm{NP}_{2} \mathrm{EO}$, the contents of BAX and BCL-2 were measured by ELISA after PC12 cells were exposed to $0-1 \mu \mathrm{g} / \mathrm{mL}$ $\mathrm{NP}_{2} \mathrm{EO}$ for $24 \mathrm{~h}$ (Fig. 7). NP ${ }_{2} \mathrm{EO}$ significantly decreased BAX contents in PC12 cells cultured in serum-free medium (Fig. 7A). However, as shown in Fig. 7B, there was no significant difference in the contents of BCL-2 between the cells cultured in serum-free medium with and those without $\mathrm{NP}_{2} \mathrm{EO}$.

Similarly, the content of BAX decreased significantly in PC12 cells cultured in serum medium containing copper with 0.1 or $1 \mu \mathrm{g} / \mathrm{mL} \mathrm{NP}{ }_{2} \mathrm{EO}$ (Fig. $8 \mathrm{~A}$ ), although the content of $\mathrm{Bcl}-2$ did not change significantly in the cells cultured on copper containing medium with and without $\mathrm{NP}_{2} \mathrm{EO}$ (Fig. 8B).

\section{DISCUSSION}

This study confirmed that $\mathrm{NP}_{2} \mathrm{EO}$ inhibits apoptosis induced by serum deprivation through examining cell viability (Fig. 1), DNA fragmentation (Fig. 3), and by copper exposure through cell 
viability (Fig. 2), DNA fragmentation (Fig. 4). In addition, there was no cytotoxicity in PC12 cells cultured in serum containing medium with 0.1 or $1 \mu \mathrm{g} / \mathrm{mL} \mathrm{NP}{ }_{2} \mathrm{EO}$, and DNA fragmentation was not observed in these cells (Fig. 3A). The results indicated that the short chain NPEOs do not induce apoptosis. However, compared to PC12 cells without $\mathrm{NP}_{2} \mathrm{EO}$, the cytotoxicity of cells increased

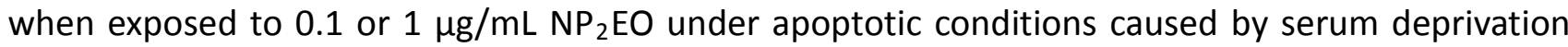
(Fig. 1B), whereas $\mathrm{NP}_{2} \mathrm{EO}$ caused a significant decrease in DNA fragmentation (Fig. 3c). These results indicated that $\mathrm{NP}_{2} \mathrm{EO}$ inhibits apoptosis caused by serum deprivation. This finding is additionally supported by the results presented in Fig. 2 . These results suggest that $\mathrm{NP}_{2} \mathrm{EO}$ could significantly recover the cytotoxicity of cells exposed to $\mathrm{CuSO}_{4}$ because $\mathrm{CuSO}_{4}$ is known to induce apoptosis (Woodgate et al., 1999). In addition, DNA fragmentation decreased with addition of $\mathrm{NP}_{2} \mathrm{EO}$ (Fig. 4). These results indicated that $\mathrm{NP}_{2} \mathrm{EO}$ inhibits apoptosis activity caused by copper exposure.

It has been demonstrated that NP induces apoptosis (Bechi et al., 2006; Kuo et al., 2012). Furthermore, Aoki et al. (2004) reported that NP enhances apoptosis induced by serum deprivation. Yet, the current study showed that $\mathrm{NP}_{2} \mathrm{EO}$ did not induce apoptosis, and that it inhibited apoptosis induced by serum deprivation and copper exposure. Previous studies have indicated that NP cytotoxicity was higher than the short chain NPEOs (Teneyck and Markee, 2007). Therefore, the strength of toxicity might depend on the length of EO chain, because NP can be defined as $\mathrm{NP}_{0} \mathrm{EO}$.

The current study also aims to determine whether oxidative stress contributes to the observed changes in apoptotic status caused by short chain NPEOs. Cytochrome c release in apoptotic PC12 cells that were and were not exposed to NPEOs was measured by western blotting. Serum deprivation and copper exposure increased the amount of cytochrome c release from mitochondria (Figs. 5 and 6). This increase was because of the disruption of mitochondrial membrane caused by ROS production (Atlante et al., 2000; Kawakami et al., 2008). The cytochrome c release decreased when PC12 cells were exposed to $\mathrm{NP}_{2} \mathrm{EO}$ under the apoptotic condition. These results might be due to $\mathrm{NP}_{2} \mathrm{EO}$ causing a reduction in oxidative stress. However, previous research showed that NP exposure induced apoptosis in the liver of malt rats, and enhanced the expression of cytochrome $c$ with increasing oxidative stress (Jubendradass et al., 2012). EO chain length might influence the difference in the toxicity between NP and short chain NPEOs; however, the actual mechanism remains unclear. To elucidate the different toxicity of these two compounds, examination of $\mathrm{NP}_{2} \mathrm{EO}$ under the apoptotic conditions is required. 
Serum deprivation has been reported to induce apoptosis in PC12 cells (Maroto and Perez-Polo, 1997). Results obtained in our laboratory suggested that NP enhanced apoptosis by serum deprivation in PC12 cells (Aoki et al., 2004) as indicated by the caspase-3 pathway. In comparison, the contents of $B A X$ and $B C L-2$ from the BCL-2 family were not altered, with only the content of BAD increasing. These results indicated that enhanced apoptotic cell death might be dependent on the pathway regulating the release of cytochrome $\mathrm{c}$ from mitochondria. It has been reported that cytochrome $\mathrm{c}$ is released from the mitochondria when apoptosis is induced (Gao et al., 2001). In the current study, it was observed that the relative release of cytochrome c in PC12 cells treated with $\mathrm{NP}_{2} \mathrm{EO}$ decreased in serum-free medium and medium containing copper. In addition, the contents of BAX from the BCL-2 family decreased significantly in PC12 cells under apoptotic conditions after exposure to $\mathrm{NP}_{2} \mathrm{EO}$ (Figs. 7 and 8 ). These results indicated that $\mathrm{NP}_{2} \mathrm{EO}$ might inhibit apoptotic pathway because of reduction of Bax contents. It has been reported that tributyl tin and 2,4,5-T completely inhibit apoptosis induced by serum deprivation, decreasing both Bax and proapoptotic protein content (Yamanoshita et al., 2000; 2001). Hence, $\mathrm{NP}_{2} \mathrm{EO}$ might have a similar impact on the apoptosis of PC12 cells to these compounds. Therefore, the addition of $\mathrm{NP}_{2} \mathrm{EO}$ affects Bcl-2 family protein expression, and hence, affects apoptosis induced by serum deprivation or copper exposure.

In conclusion, $\mathrm{NP}_{2} \mathrm{EO}$ inhibited apoptosis induced by serum deprivation and copper. $\mathrm{NP}_{2} \mathrm{EO}$ exhibited the opposite effect on apoptosis in PC12 cells compared to NP, which might be due to the difference in the structure of the two compounds, along with different response mechanisms to apoptosis. Ultimately, further investigation is required to clarify the precise toxicity mechanism of short chain NPEOs and NP.

\section{Declaration of Interest}

The authors declare that there are no conflicts of interest.

\section{REFERENCES}

Ahel M, Giger W, Koch M. 1994. Behavior of alkylphenol polyethoxylates surfactants in the aquatic environment - I. Occurrence and transformation in sewage treatment. Water Res 28:1131-1142. Aoki M, Kurasaki M, Saito T, Seki S, Hosokawa T, Takahashi Y, Fujita F, Iwakuma T. 2004. Nonylphenol enhances apoptosis induced by serum deprivation in PC12 cells. Life Sci 74:2301-2312. 
APERC (Alkylphenols and Ethoxylates Research Council). 2006. Alkylphenols and Alkylphenol Ethoxylates-Product Uses. Alkylphenols and Ethoxylates Research Council, Washington, DC, USA. Atlante A, Calissano P, Bobba A, Azzariti A, Marra E, Passarella S. 2000. Cytochrome c Is Released from Mitochondria in a Reactive OxygenSpecies (ROS)-dependent Fashion and Can Operate as a ROS Scavenger and as a Respiratory Substrate in Cerebellar Neurons Undergoing Excitotoxic Death. J Biol Chem 275:37159-37166.

Balch G, Metcalfe C. 2006. Developmental effects in Japanese medaka (Oryziaslatipes) exposed to nonylphenolethoxylates and their degradation products. Chemosphere 62:1214-1223.

Bechi N, letta F, Romagnoli R, Focardi S, Corsi I, Buffi C, Paulesu L. 2006. Estrogen-like response to p-nonylphenol in human first trimester placenta and BeWo choriocarcinoma cells. Toxicol Sci 93:75-81.

Cai Q, Huang H, Lu H, Mo C, Zhang J, Zeng Q, Tian J, Li Y, Wu X. 2012. Occurrence of Nonylphenol and NonylphenolMonoethoxylate in Soil and Vegetables from Vegetable Farms in the Pearl River Delta, South China. Arch Environ ContamToxicol 63:22-28.

Chapin RE, Delaney J, Wang Y, Lanning L, Davis B, Collins B, Mintz N, Wolfe G. 1999. The effects of 4-nonylphenol in rats: A multigeneration reproduction study. Toxicol Sci 52:80-91.

Ferguson SA, Flynn KM, Delclos KB, Newbold RR. 2000. Maternal and offspring toxicity but few sexually dimorphic behavioral alterations result from nonylphenol exposure. Neurotoxicol Teratol 22:583-591.

Gao W, Pu Y, Luo KQ, Chang DC, 2001. Temporal relationship between cytochrome c release and mitochondrial swelling during UV-induced apoptosis in living HeLa cells. J Cell Sci $114: 2855-2862$.

Goto R, Kubota T, Ibuki Y, Kaji K, Go A. 2004. Degradation of nonylpheno Ipolyethoxylates by ultraviolet B irradiation and effects of their products on mammalian cultured cells. Toxicology 202:237-247.

Greene LA, Tischler AS. 1976. Establishment of a noradrenergic clonal line of rat adrenal pheochromocytoma cells which respond to nerve growth factor. Proc Natl Acad Sci $173: 2424-2428$

Jobling S, Sheahan D, Osborne JA, Matthiessen P, Sumpter JP. 1996. Inhibition of testicular growth in rainbow trout (Oncorhynchusmykiss) exposed to estrogenic alkylphenolic chemicals. Environ 
Toxicol Chem 15:194-202.

Jubendradass R, Cynthia D'Cruz SC, Amala J, Rani S, Mathur PP. 2012. Nonylphenol induces apoptosis via mitochondria- and Fas-L-mediated pathways in the liver of adult male rat. Regulatory Toxicology and Pharmacology 62:405-411.

Kawakami M, Inagawa R, Hosokawa T, Saito T, Kurasaki M. 2008. Mechanism of apoptosis induced by copper in PC12 cells. Food Chem Toxicol 46:2157-2164.

Knudsen FR, Pottinger TG. 1999. Interaction of endocrine disrupting chemicals, singly and in combination, with estrogen-, androgen-, and corticosteroid- binding sites in rainbow trout (Oncorhynchus mykiss). Aquat Toxicol 44:159-170.

Kuo PL, Hsu YL, Tsai MJ, Lien CT, Huang MS, Ko YC. 2011. Nonylphenol induces bronchial epithelial apoptosis via Fas-mediated pathway and stimulates bronchial epithelium to secrete IL-6 and IL-8, causing bronchial smooth muscle proliferation and migration. Basic Clin Pharmacol Toxicol 110:178-186.

Laws SC, Carey SA, Ferrell JM, Bodman GJ, Cooper RL. 2000. Estrogenic activity of octylphenol, nonylphenol, bisphenol A and methoxychlor in rats. Toxicol Sci 54:156-167.

Lee PC, Lee W. 1996. In vivo estrogenic action of nonylphenol in immature female rats. Bull Environ Contam Toxicol. 57:341-348.

Loo TW, Clarke DM. 1998. Nonylphenol ethoxylates, but not nonylphenol, are substrates of the human multidrug resistance P-glycoprotein. Biochem Biophys Res Commun.247:478-480.

Masuno H, Okamoto S, Iwanami J, Honda K, Shiosaka T, Kidani T, Sakayama K, Yamamoto H. 2003. Effect of 4-nonylphenol on cell proliferation and adipocyte formation in cultures of fully differentiated 3T3-L1 cells. Toxicol Sci 75:314-320.

Maroto R, Perez-Polo JR. 1997. BCL-2-related protein expression in apoptosis: oxidative stress versus serum deprivation in PC12 cells. J Neurochem 69:514-523.

Nagao T, Wada K, Marumo H, Yoshimura S, Ono H. 2001. Reproductive effects of nonylphenol in rats after gavage administration: a two-generation study. Reprod Toxicol 15:293-315.

Naylor CG. 1995. The Environmental Fate and Safety of Nonylphenol Ethoxylates. International Conference \& Exhibition;AATCC 1133-1152.

Obata T, Kubota S. 2000. Formation of hydroxyl radicals by environmental estrogen-like chemicals in rat striatum. Neurosci Lett 296:41-44. 
Odum J, Pyrah IT, Soames AR, Foster JR, Van Miller JP, Joiner RL, Ashby J. 1999. Effects of p-nonylphenol (NP) diethylstilbestrol (DES) on the alderley Park (Alpk) rat: Comparison of mammary gland and uterus sensitivity following oral gavage or implanted mini-pumps. J Appl Toxicol 19:367-378.

Qi Y, Zhang Y, Liu Y, Zhang W. 2013. Nonylphenol decreases viability and arrests cell cycle via reactive oxygen species in Raji cells. Exp Toxicol Pathol 65:69-72.

Ravni A, Bourgault S, Lebon A, Chan P, Galas L, Fournier A, Vaudry H, Gonzalez B, Eiden LE, Vaudry D. 2006. The neurotrophic effects of PACAP in PC12 cells: control by multiple transduction pathways. J Neurochem 98:321-329.

Scott-Fordsmand JJ, Krogh PH. 2004. The influence of application form on the toxicity of nonylphenol to Folsomiafimetaria (Collembola: Isotomidae). Ecotoxicol Environ Saf 58:294-299.

Seki M, Yokota H, Maeda M, Tadokoro H, Kobayashi K. 2003. Effects of 4-nonylphenol and 4-tert-octylphenol on sex differentiation and vitellogenin induction in medaka (Oryziaslatipes). Environ Toxicol Chem 22:1507-1516.

Sharma VK, Anquandah GA, Yngard RA, Kim H, Fekete J, Bouzek K, Ray AK, Golovko D. 2009. Nonylphenol, octylphenol, and bisphenol-A in the aquatic environment: a review on occurrence, fate, and treatment. J Environ Sci Health A 44:423-442.

Soares A, Guieysse B, Jefferson B, Cartmell E, Lester JN. 2008. Nonylphenol in the environment: a critical review on occurrence, fate, toxicity and treatment in wastewaters. Environ Int 34:1033-1049.

Stasinakis AS, Gatidou G, Mamais D, Thomaidis NS, Lekkas TD. 2008. Occurrence and fate of endocrine disrupters in Greek sewage treatment plants. Water Res 42:1796-1804.

Teneyck MC, Markee TP. 2007. Toxicity of nonylphenol, nonylphenol monoethoxylate, and nonylphenol diethoxylate and mixtures of these compounds to pimephalespromelas (fathead minnow) and ceriodaphniadubia. Arch Environ Contam Toxicol 53:599-606.

Tollefsen KE, Blikstad C, Eikvar S, Finne EF, Gregersen IK. 2008. Cytotoxicity of alkyphenols and alkylated non-phenolics in a primary culture of rainbow trout (Onchorhynchusmykiss) hepatocytes. Ecotoxicol Environ Safe 69:64-73.

Tollefsen KE, Ingebrigtsen K, Olsen AJ, Zachariassen KE, Johnsen S. 1998. Acute toxicity and toxicokinetics of 4-heptylphenol in juvenile Atlantic cod (Gadusmorhua L.). Environ Toxicol Chem 
17:740-746.

Toyooka T, Kubota T, Ibuki Y. 2012. Nonylphenol polyethoxylates induce phosphorylation of histone H2AX. Mutat Res 741:57-64.

Vaudry D, Chen Y, Hsu CM, Eiden LE. 2002. PC12 cells as a model to study the neurotrophic activities of PACAP. Ann. NY Acad Sci 971:491-496.

Vazquez-Duhalt R, MarquezRoche F, Ponce E, Licea AF, Viana MT. 2005 Nonylphenol, an integrate dvision of apollutant. Appl Ecol Environ Res 4:1-25.

Woodgate A, MacGibbon G, Walton M, Dragunow M. 1999. The toxicity of 6-hydroxydopamine on PC12 and P19 cells. Brain Res Mol Brain Res 69:84-92.

Yamanoshita O, Kurasaki M, Saito T, Takahasi K, Sasaki H, Hosokawa T, Okabe M, Mochida J, Iwakuma T. 2000 Diverse effect of tributyltin on apoptosis in PC12 cells. Biochem Biophys Res Commun 272:557-562.

Yamanoshita O, Saito T, Takahashi K, Hosokawa T, Okabe M, Ito K, Kurasaki M. 2001. 2,4,5-Trichlorophenoxyacetic acid inhibits apoptosis in PC12 cells. Life Sci 69:403-408.

Ying GG, 2006. Fate, behavior and effects of surfactants and their degradation products in the environment. Environ Int 32:417-431. 


\section{Figure Captions}

Fig. 1 - Cell viability of PC12 cells in medium with (A) and without (B) serum containing 0-1 $\mu \mathrm{g} / \mathrm{mL}$ $\mathrm{NP}_{2} \mathrm{EO}$ after $72 \mathrm{~h}$. Error bars indicate SEM $(n=6) .{ }^{* *}$ indicates significant difference at $p<0.01$.

Fig. 2 - Cell viability of PC12 cells exposed to $500 \mu \mathrm{M} \mathrm{CuSO}_{4}$ containing 0-1 $\mu \mathrm{g} / \mathrm{mL} \mathrm{NP}_{2}$ EO for $72 \mathrm{~h}$. In the upper panel, A, B, C and D mean control (cell without treatment), cells treated with $500 \mu \mathrm{M}$ $\mathrm{CuSO}_{4}$, cells treated with $500 \mu \mathrm{M} \mathrm{CuSO}_{4}$ and $0.1 \mu \mathrm{g} / \mathrm{mL} \mathrm{NP}{ }_{2} \mathrm{EO}$ and cells treated with $500 \mu \mathrm{M} \mathrm{CuSO}_{4}$ and $1.0 \mu \mathrm{g} / \mathrm{mL} \mathrm{NP}{ }_{2} \mathrm{EO}$, respectively. In Automated Cell Counter, green and red images indicate live and dead cells, respectively. In lower panel, Error bars indicate SEM $(\mathrm{n}=3) .{ }^{* *}$ indicates significant difference at $p<0.01$.

Fig. 3 DNA fragmentation of PC12 cells cultured in serum-containing medium (A) and serum-free medium (B) for $72 \mathrm{~h}$ after exposure to $0-1 \mu \mathrm{g} / \mathrm{mL} \mathrm{NP}{ }_{2}$ EO. Fragmentation was evaluated by measurement of density (C) M indicates $\lambda D N A$ digested by HindlII as a DNA marker. Error bars indicate SEM $(n=3) .^{*}$ and ${ }^{* *}$ indicate significant differences at $p<0.05$ and $p<0.01$, respectively.

Fig. 4 DNA fragmentation of PC12 cells cultured in serum containing medium with $0-500 \mu \mathrm{M} \mathrm{CuSO}_{4}$ and $0-1 \mu \mathrm{g} / \mathrm{mL} \mathrm{NP}{ }_{2} \mathrm{EO}$ for $72 \mathrm{~h}(\mathrm{~A})$. Fragmentation was evaluated by the measurement of DNA ladder patterns (B) and the density (C). M indicates $\lambda$ DNA digested by HindIII as a DNA marker. Error bars indicate SEM $(n=3) .{ }^{*}$ and $* *$ indicate significant differences at $p<0.05$ and $p<0.01$, respectively.

Fig. 5 Representative western blot analyses for cytochrome c release in PC12 cells cultured in serum-containing medium (A) and serum-free medium (B) for $72 \mathrm{~h}$ after exposure to $0-1 \mu \mathrm{g} / \mathrm{mL}$ $\mathrm{NP}_{2} \mathrm{EO}$. Error bars indicate SEM $(\mathrm{n}=3)$. The typical pattern and mean intensity of staining by representative western blot analyses are shown in the upper and lower panels of the figure, respectively. ${ }^{*}$ and $* *$ indicate significant differences at $p<0.05$ and $p<0.01$, respectively.

Fig. 6 Representative western blot analyses for cytochrome c release in PC12 cells cultured in serum medium containing 0-500 $\mathrm{MM} \mathrm{CuSO}_{4}$ for $72 \mathrm{~h}$ after exposure to $0-1 \mu \mathrm{g} / \mathrm{mL} \mathrm{NP}{ }_{2}$ EO. Error bars indicate SEM $(n=5)$. The typical pattern and mean intensity of staining by representative western 
blot analyses are shown in the upper and lower panels of the figure, respectively. ${ }^{*}$ and $* *$ indicate significant differences at $p<0.05$ and $p<0.01$, respectively.

Fig. 7 The contents of $B A X(A)$ and $B C L-2(B)$ in PC12 cells cultured in serum-containing medium or serum-free medium for $24 \mathrm{~h}$ after exposure to $0-1 \mu \mathrm{g} / \mathrm{mL} \mathrm{NP}{ }_{2}$ EO. Error bars mean SEM $(\mathrm{n}=6)$ * $^{*}$ and $* * *$ indicate significant differences at $p<0.05$ and $p<0.001$, respectively.

Fig. 8 The contents of BAX (A) and BCL-2 (B) in PC12 cells cultured in serum medium containing 0-500 $\mu \mathrm{M}$ CuSO4 for $72 \mathrm{~h}$ after exposure to 0-1 $\mu \mathrm{g} / \mathrm{mL}$ NP2EO. Error bars mean SEM $(\mathrm{n}=6) *^{*}$ and $* * *$ indicate significant differences at $p<0.05$ and $p<0.001$, respectively. 


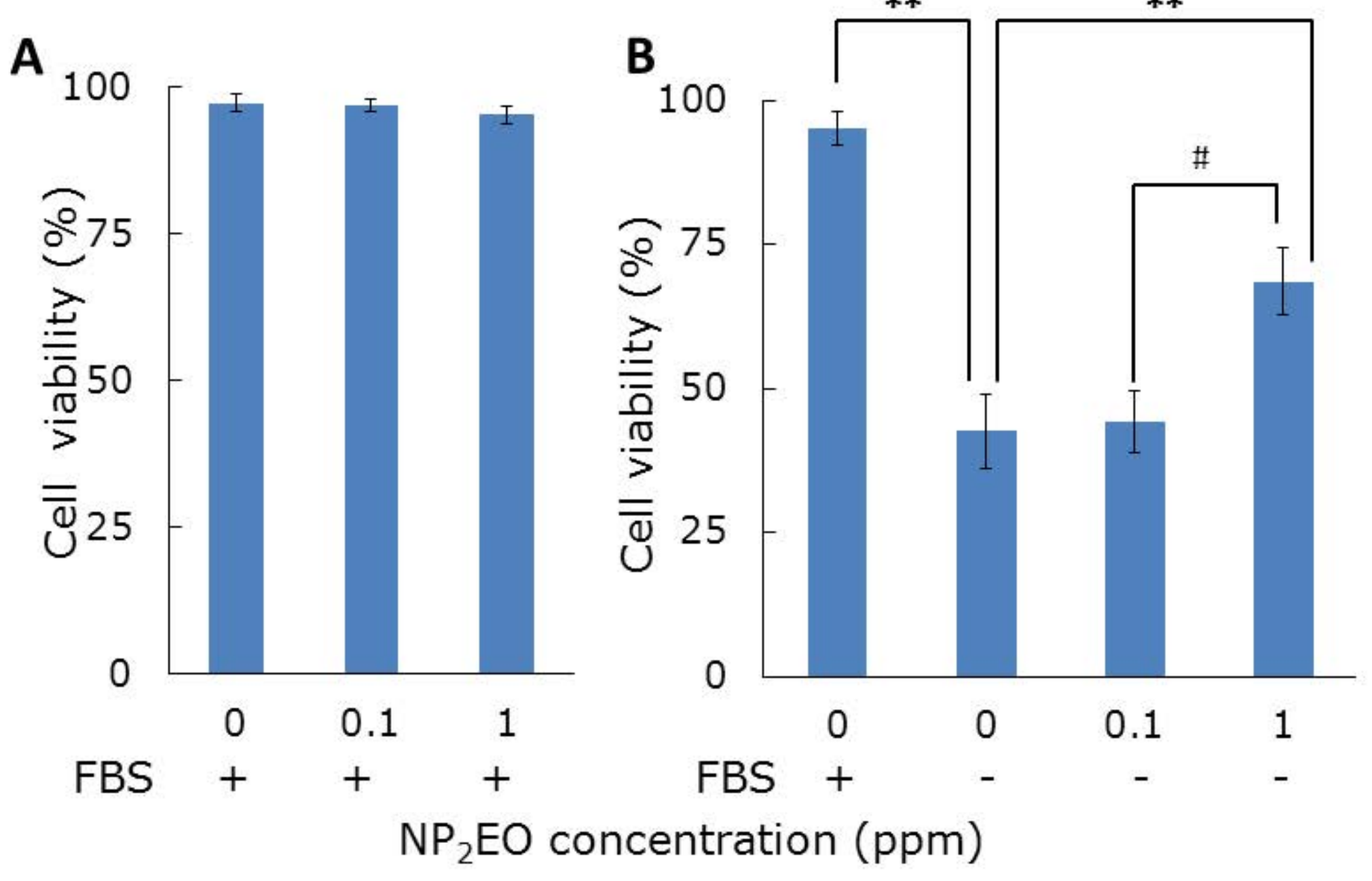




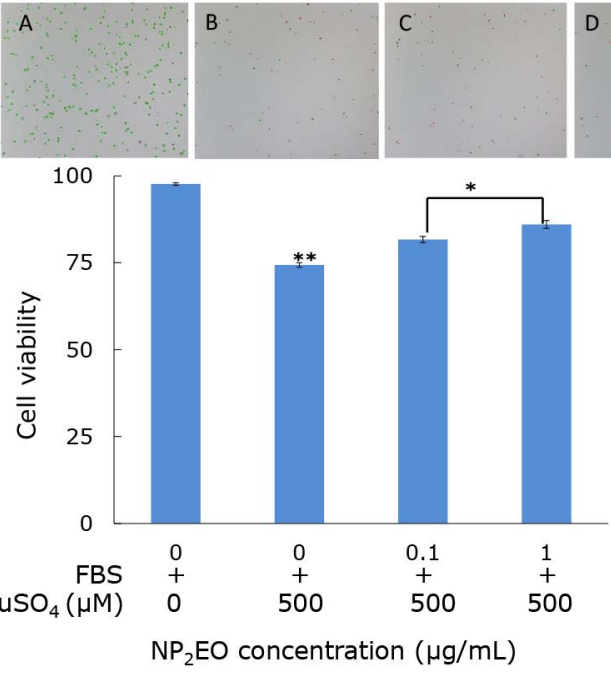




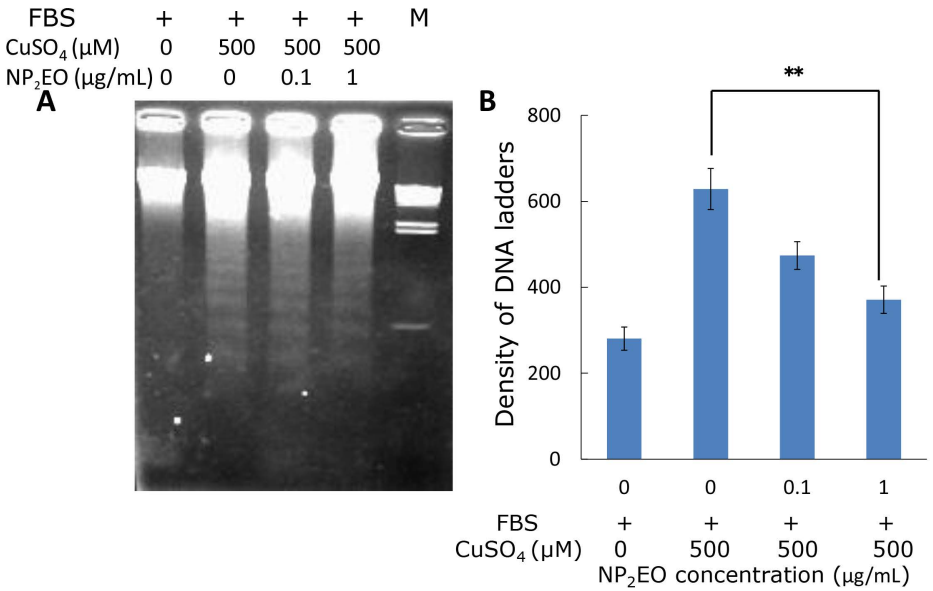




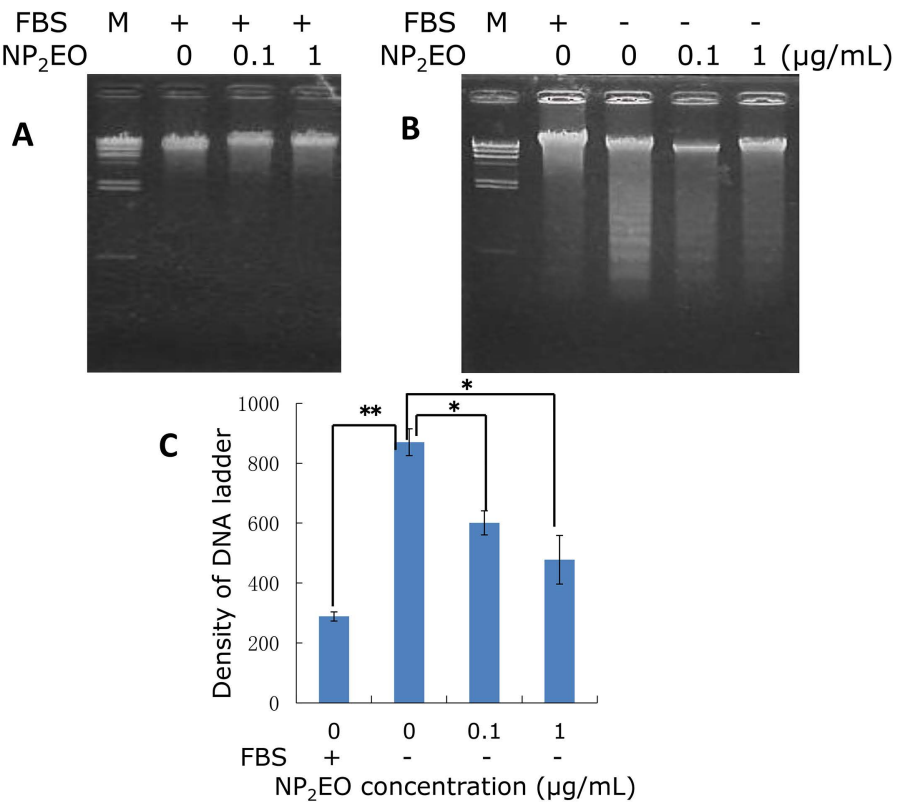


$\begin{array}{lllllll}\mathrm{NP}_{2} \mathrm{EO}(\mu \mathrm{g} / \mathrm{mL}) & 0 & 0 & 0.1 & 1 \mathrm{NP}_{2} \mathrm{EO}(\mu \mathrm{g} / \mathrm{mL}) 0 & 0.1 & 1\end{array}$

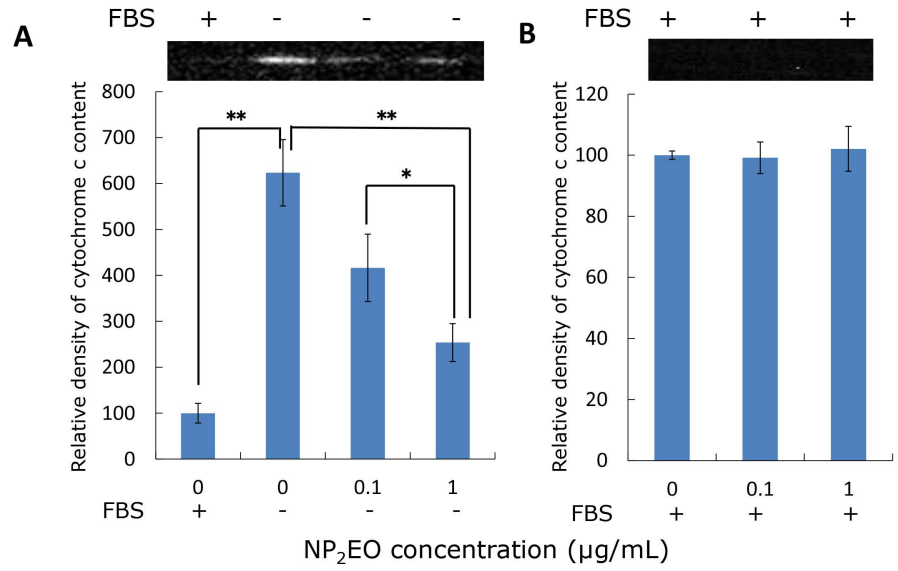




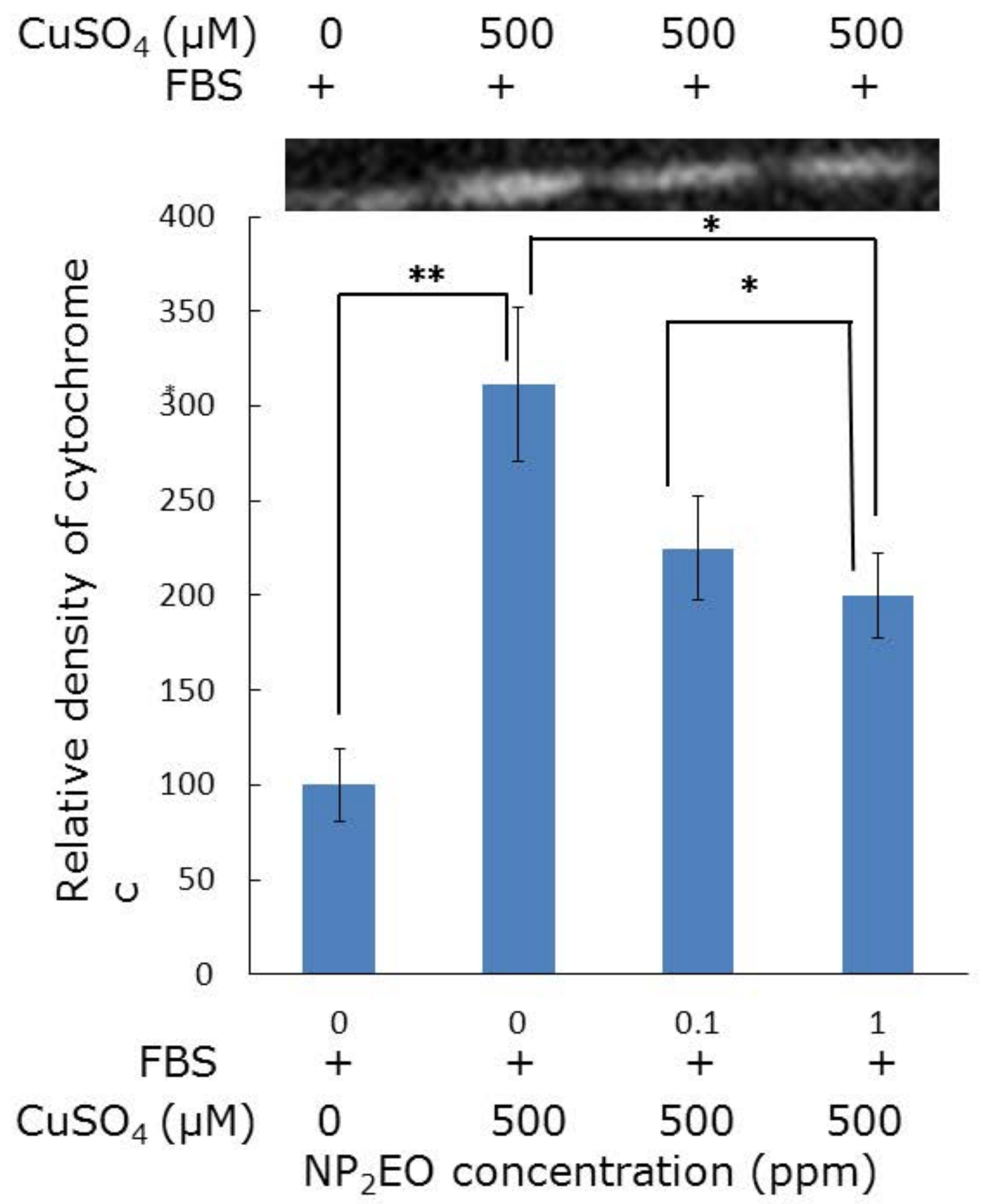




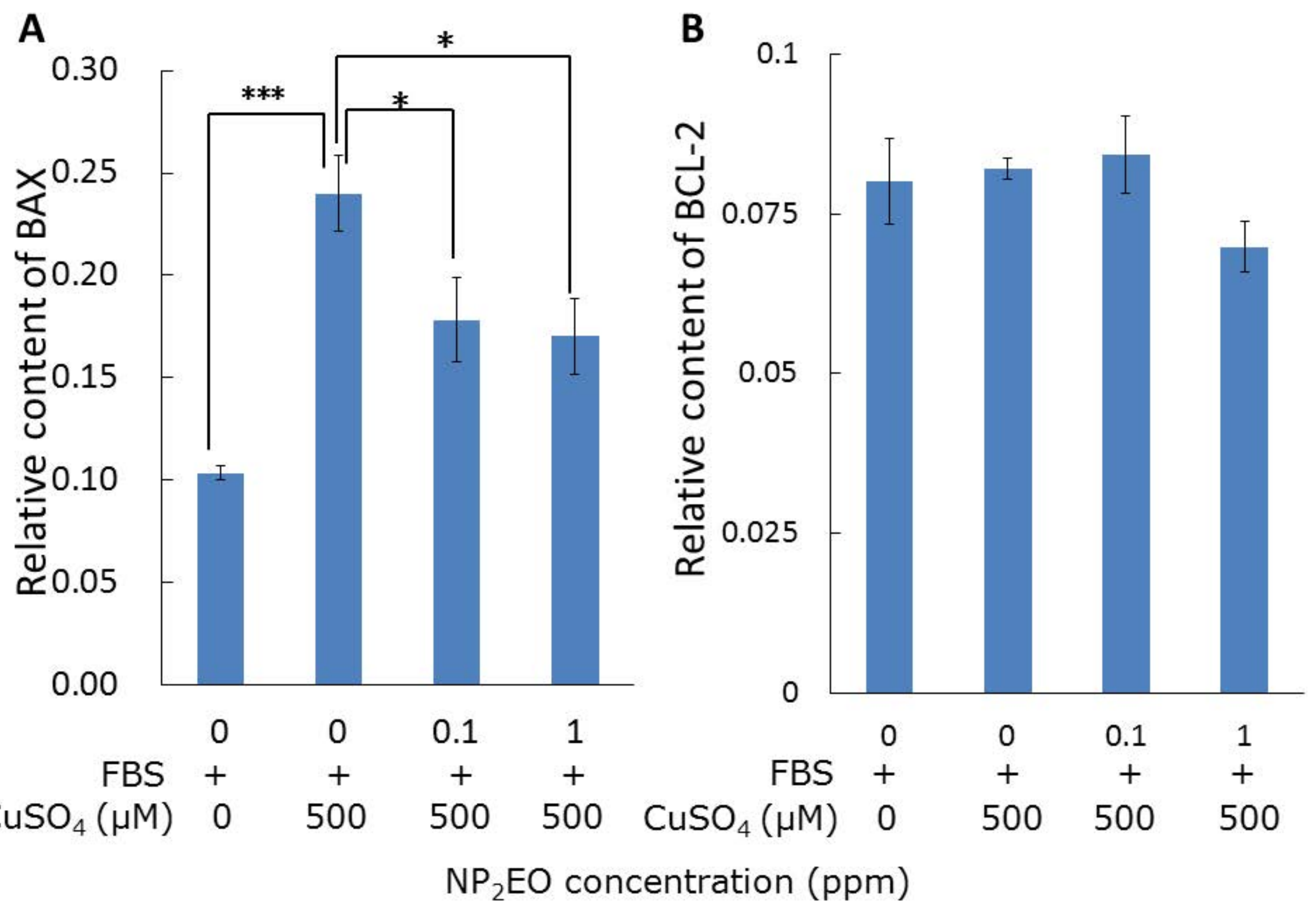




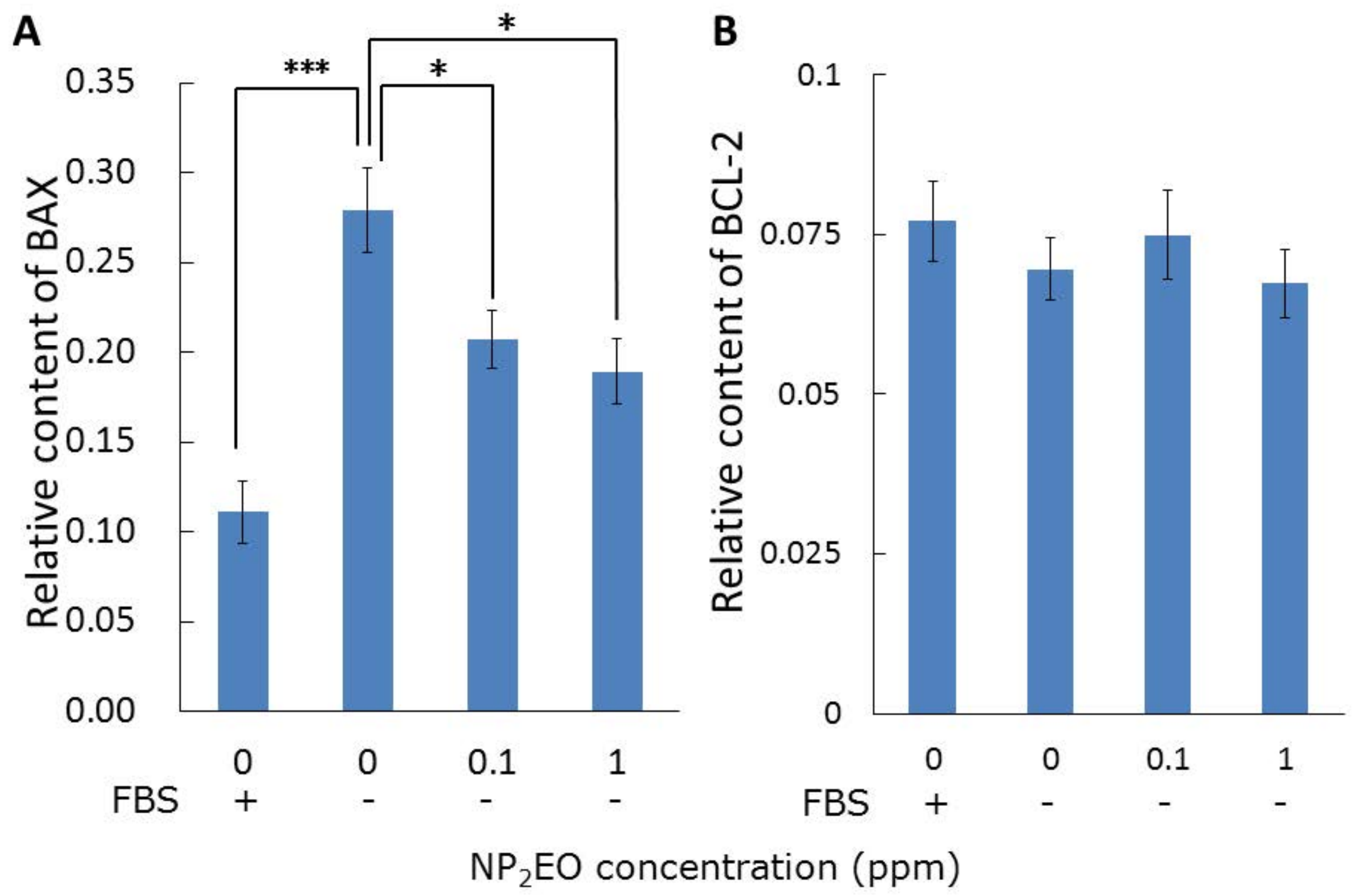

